\title{
An aeolian or a glaciolacustrine record? A case study from Miel̦upīte, Middle Gauja Lowland, northeast Latvia
}

\author{
Māris Nartišs ${ }^{1} \&$ Edyta Kalińska-Nartiša ${ }^{2 *}$ \\ ${ }^{1}$ Faculty of Geography and Earth Sciences, University of Latvia, Jelgavas iela 1, Riga, LV-1004 Latvia \\ ${ }^{2}$ SunGIS SIA, Pruuni, Rencēni Parish, Burtnieki region, LV-4232 Latvia \\ *corresponding author, e-mail: edyta.kalinska@gmail.com
}

\begin{abstract}
In the Middle Gauja Lowland, northeast Latvia, dunes are distributed over a vast glaciolacustrine plain that formed during the retreat of the Fennoscandian ice sheet. Such a direct contact between aeolian and glaciolacustrine sediments can be used to infer depositional settings and decipher to what extent these sediments bear an aeolian component. Our proxies, although preliminary, reveal a limited range of variation in grain-size parameters, a significant presence of quartz grains with silica precipitation and matt-surface grains of various rounding degrees and massive structure combined with horizontal lamination. These are indicative of periglacial-aeolian depositional conditions in the foreland of the Linkuva ice-marginal zone. Sedimentary characteristics do not match a single luminescence date of $9.2 \pm 0.6 \mathrm{ka}$, which significantly postdates the minimum age of the Linkuva ice-marginal zone with ${ }^{10} \mathrm{Be}$ ages between 15.4 and 12.0 $\mathrm{ka}$. Whether deposition started directly after drainage of the Middle Gauja ice-dammed lake or if there is a gap of 2.8-6.2 $\mathrm{ka}$ is a matter of debate; only future studies at higher OSL resolution could resolve this.
\end{abstract}

Keywords: dune, ice-dammed lake, quartz grains, optically stimulated luminescence, Linkuva ice-marginal zone, Baltic States

\section{Introduction}

Pleistocene aeolian processes shaped large areas of the European landscape and encapsulated evidence of environmental conditions in former times. One of the most prominent features is the European sand belt, a zone of aeolian landforms stretching from Great Britain to the Ural Mountains (Zeeberg, 1998), resembling a continuous sand belt across western and central Europe (Antoine et al., 2003; Kolstrup, 2007; Crombé et al., 2012; Roskosch et al., 2012; Vandenberghe et al., 2013; Küster et al., 2014). In places this belt is discontinuous and scattered; such a situation prevails in northern Europe (Zeeberg, 1998; Käyhkö et al., 1999; Matthews
\& Seppälä, 2013; Alexanderson \& Henriksen, 2015; Kalińska-Nartiša et al., 2015a).

However, an aeolian imprint is not only seen in landforms of aeolian origin such as dunes and coversands, but is widely known from sediments formed in a number of settings, e.g., fluvial (Zhang et al., 2015; Zieliński et al., 2015), lacustrine (An et al., 2012) and glacial environments (Kalińska-Nartiša \& Nartišs, 2016a), as well as soils (Tate et al., 2007), caves (Krajcarz et al., 2016) and bogs (Björck \& Clemmensen, 2004; Margielewski et al., 2015). This aeolian sedimentary component has been proved to constitute a powerful tool in reconstructions of the climatic history of each environment. Therefore, efforts must be made to decipher aeolian records 
from other sediments. This is the case of the Middle Gauja Lowland, northeast Latvia, where aeolian strata are concentrated in dune complexes of up to 25 landforms per $\mathrm{km}^{2}$ (Celinš et al., 2014), distributed over vast glaciolacustrine plains that are remnants after large ice-dammed lakes formed during the retreat of the Fennoscandian ice sheet. These sandy glaciolacustrine sediments border directly adjacent to aeolian complexes and consequently served as the main source during aeolian processes.

In the present study we focus entirely on the Mielypite section, which is assumed to represent a typical glaciolacustrine-aeolian sediment contact within the region (Celinšs et al., 2014; Kalińska-Nartiša et al., 2014). However, the glaciolacustrine sediments at Mielupîte are represented by clays and this contrasts with the predominantly sandy glaciolacustrine record in the remainder of the region (see below). Such a specific clay-sand relationship, a lack of available sediment data and chronology and availability of a fresh road-cutting make the Mielupīte site ideal for a novel study of the glaciolacustrine-aeolian contact in northeast Latvia.

By combining detailed sediment analyses (structure, grain size distribution, morphoscopy of quartz grains, microtextures on sand grain surface and mineral content) and limited chronological data (optically stimulated luminescence $=$ OSL), we aim to answer these research questions: (1) what is characteristic of glaciolacustrine-aeolian contacts with respect to sedimentary features, (2) when did deposition take place, and (3) to what extent can the aeolian signature be distinguished in the strata studied.

\section{Geological background}

A number of ice streams operated in the territory of present-day Latvia during the Last Glaciation (Zelčs et al., 2011). One of these was the Peipsijärv (Peipsi) ice stream and its Middle Gauja ice lobe, which is believed to have formed the Middle Gauja Lowland (Zelčs \& Markots, 2004). This ice lobe was responsible for the formation of a large icedammed lake between the Gulbene (Middle Lithuanian = Słupsk Bank Phase; compare Böse et al., 2012; Marks, 2012) and Linkuva (North Lithuanian $=$ South Middle Bank Phase) deglaciation phases which covered most of the Middle Gauja Lowland (Celiņš et al., 2014). Palaeogeographical reconstructions of the Middle Gauja ice-dammed lake indicate a stepwise drop of the water level (Nartišs, 2014), leading to emergence of the Miellupite site in the form of an up to 7-m-high island above the water

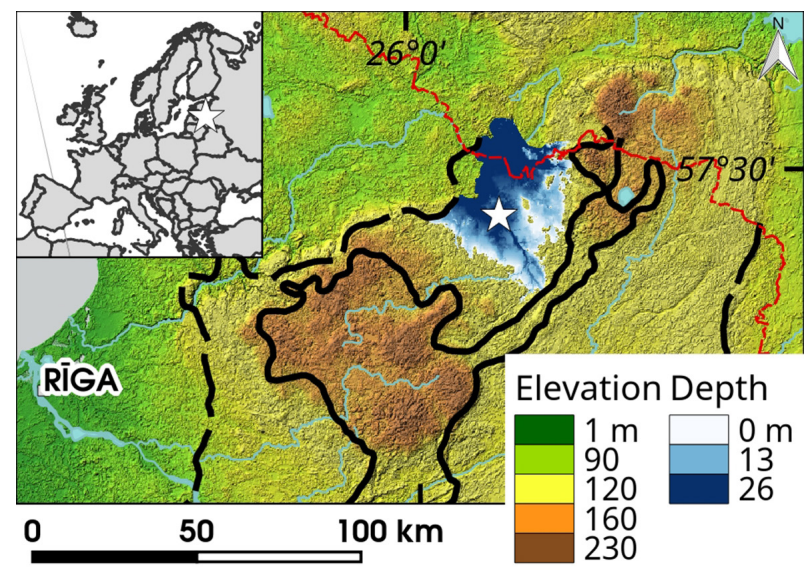

Fig. 1. General situation of the Mielupinte section (marked by a star and surrounded by the Middle Gauja icedammed lake (in blue) as proposed by Nartišs, 2014). The continuous line refers to the Gulbene ice-marginal zone; the dashed line denotes the Linkuva ice-mariginal zone (Zelčs et al., 2011).

level during the 90-m-phase in the history of the ice-dammed lake. The occurrence of ice-dammed lakes resulted in glaciolacustrine deposition that consisted largely of fine-grained sand in the central and southern part of the lowland, and of silty clay in the northern and northeastern part (Juškevičs \& Skrebels, 2002). The distribution of aeolian landforms is therefore correlated with the area of sandy glaciolacustrine sediments, since in areas with clay they are virtually absent (Celinš et al., 2014).

The Mielupite section is located approximately $20 \mathrm{~km}$ NNW of the village of Lejasciems and $1.5 \mathrm{~km}$ E of the valley of the River Gauja. It lies between the Linkuva and Gulbene ice-marginal zones (Fig. 1). The age of the Linkuva ice-mariginal zone is known from a wide distribution of ${ }^{10} \mathrm{Be}$ ages to be between 15.4 and $12.0 \mathrm{ka}$ (Rinterknecht et al., 2006). The minimum age of the Gulbene ice-marginal zone is estimated to be $13.5 \mathrm{ka}{ }^{10} \mathrm{Be}$ (Rinterknecht et al., 2006), although luminescence ages set minimum ages in the range of 14.5 to $15.5 \mathrm{ka}$ (Zelčs et al., 2011). A high density of irregular dunes, up to $10-15 \mathrm{~m}$ in height, and patchy coversands (up to $2-5 \mathrm{~m}$ in height) can be observed in the area. These aeolian landforms are distributed on the surface of a vast glaciolacustrine plain (Fig. 2).

\section{Methodology}

A 2-m-long sediment section was recovered during fieldwork in July 2011. The present study focuses on the interval between 1.1 and $1.7 \mathrm{~m}$ below surface, where a mostly undisturbed sand sequence occurs. Five sediment samples of c. $200 \mathrm{~g}$ each 


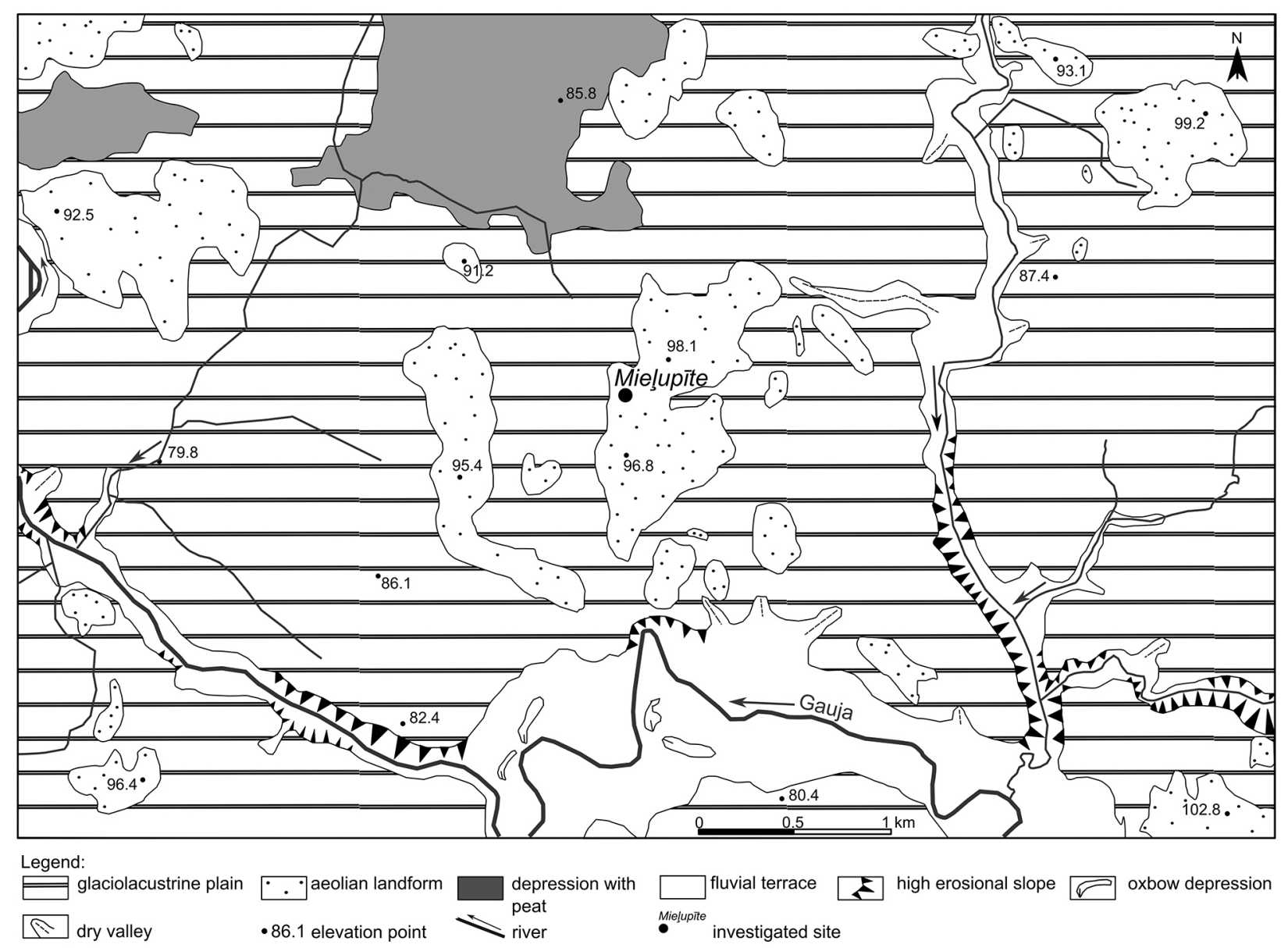

Fig. 2. Geomorphology of the Mielsupite section.

were subjected to grain size analysis. Each sample was dry sieved for 15 minutes (Román-Sierra et al., 2013) and the individual sieve fractions were weighed with a precision of $\pm 0.001 \mathrm{~g}$. Subsequently the customised version of the R package "rysgran" (Gilbert et al., 2012) was used to calculate grain size parameters: mean grain size $(\mathrm{Mz})$, sorting $(\sigma)$ and skewness (Sk), following the logarithmic graphic method (Folk \& Ward, 1957). Particle size distribution classification and terminology according Blott \& Pye (2012) was implemented. Grain size data were presented as frequency and cumulative plots.

After sieving two sandy fraction (of $0.8-1.0 \mathrm{~mm}$ and $>1.0 \mathrm{~mm}$ ) were subsampled and an optical microscope with c. $50 \times$ magnification was used to (1) estimate the level of quartz grain roundness, (2) the character of its surface $($ matt $=$ dull or shiny $=$ glossy) and (3) the mineral characteristic of the sediment.

Quartz roundness and surface were evaluated by visual determination by two methodological approaches. For the $0.8-1.0 \mathrm{~mm}$ fraction between 120 and 150 quartz grains were analysed and the primary methodology of Cailleux (1942; as modified by
Mycielska-Dowgiałło \& Woronko 1998) was used, where seven types of grains can be distinguished. These are: (1) aeolian, well rounded and with matt surface across the entire grain, (2) aeolian partially rounded, with matt surface only on the most convex part of the grain, (3) well-rounded and shiny correlated with a high-energy aqueous environment, (4) partially rounded and shiny (high-energy aqueous environment), (5) with all fresh surfaces and sharp edges, and without visible chemical weathering, (6) cracked, and finally (7) with very intensively weathering by silica precipitation and solution in situ.

The second approach with five groups of grain roundness ( 0 to IV, where 0 - non-abraded, and IV - rounded), combined with four categories of grain surface (shiny, quarter-matt, half-matt and matt) as proposed by Velichko \& Timirieva (1995) was used, in contrast, for the $>1.0 \mathrm{~mm}$ fraction with $c$. 50 quartz grains. Subsequently, roundness (Q) and dullness $\left(\mathrm{F}_{\mathrm{m}}\right)$ coefficients were calculated using these formulas:

$$
Q=\frac{0 \cdot n_{0}+1 \cdot n_{1}+2 \cdot n_{2}+3 \cdot n_{3}+4 \cdot n_{4}}{\sum n} \cdot 25
$$


where $\mathrm{n}_{0,1,2,3,4}$ is the quantity of grains belonging to classes $0,1,2,3$ and 4 , respectively, and $\Sigma \mathrm{n}$ is the total quantity of grains studied, and

$$
F_{m}=\frac{0 \cdot F+0.25 \cdot N M+0.5 \cdot F M+1 \cdot M}{\sum n} \cdot 100
$$

where F represent the number of shiny grains, NM are of quarter-matt, FM that of half-matt, and M of matt grains. $\Sigma \mathrm{n}$ is the total number of grains studied.

Scanning Electron Microscope (SEM) analysis was done of quartz grains from two sediment samples from a depth of $1.3 \mathrm{~m}$ (16 grains) and 1.7 $\mathrm{m}$ (18 grains) in order to score surface microfeatures. Prior to analysis, sample preparation was performed according to procedures described by Krinsley \& Doornkamp (1973). The subsampled 0.8-1.0 mm fraction was treated with hydrochloric acid for a short moment and subsequently washed thoroughly with deionised water. After oven-drying, grains were positioned in row-patterns onto a double sticky tape on top of an SEM stub and sputter-coated with gold. Grains were imaged using SEM with (1) c. $100 \times$ to determine general outline, i.e., rounding and relief, and (2) c. 400-1,200 $x$ to determine the presence of microtextures. Their classification, based upon the occurrence of microtextures, followed Vos et al. (2014), where mechanical, chemical and mixed-origin microtextures are grouped. Finally, mechanically induced microfeatures were grouped according to proposals made by Sweet \& Soreghan (2010), where high-stress, percussion and polygenetic fractures were classified.

The mineral composition of all samples was analysed, for which 220-250 grains were randomly chosen and classified as quartz, feldspars and lithic fragments.

Absolute age dating using optically stimulated luminescence (OSL) was performed on the sample from a depth of $1.6 \mathrm{~m}$. It was collected by hammering a stainless steel cylinder into a freshly dug and cleaned section. The cylinder was dug out and sealed promptly to prevent further exposure. A separate sample was recovered for evaluation of the water-averaged content. A quartz extract was obtained by wet sieving and subsampling the 90-125 $\mu \mathrm{m}$ fraction and subsequent chemical treatments, including $\mathrm{HCl}$ and $\mathrm{H}_{2} \mathrm{O}_{2}$. Further, 40 per cent HF was used to clean the outer surface of the grains. The quartz-rich extracts were used for determination of the equivalent dose $\left(D_{e}\right)$. The single-aliquot regenerative-dose (SAR) protocol (Murray \& Wintle, 2000), followed by the Central Age Model (CAM; Galbraith et al., 1999), was used to obtain the
De based on 14 aliquots at the Silesian University of Technology, Gliwice Centre for Absolute Dating (Gliwice, Poland).

\section{Results}

The Mielupipte section consists of three units: at the bottom of the outcrop are situated light-brown and light-grey glaciolacustrine clays (1 in Figs 3, $4 \mathrm{~A}$ ); these are followed by a 50 -cm-thick sequence of four reddish-brown sand layers separated by weakly expressed, up to 2-cm-thick interlayers of

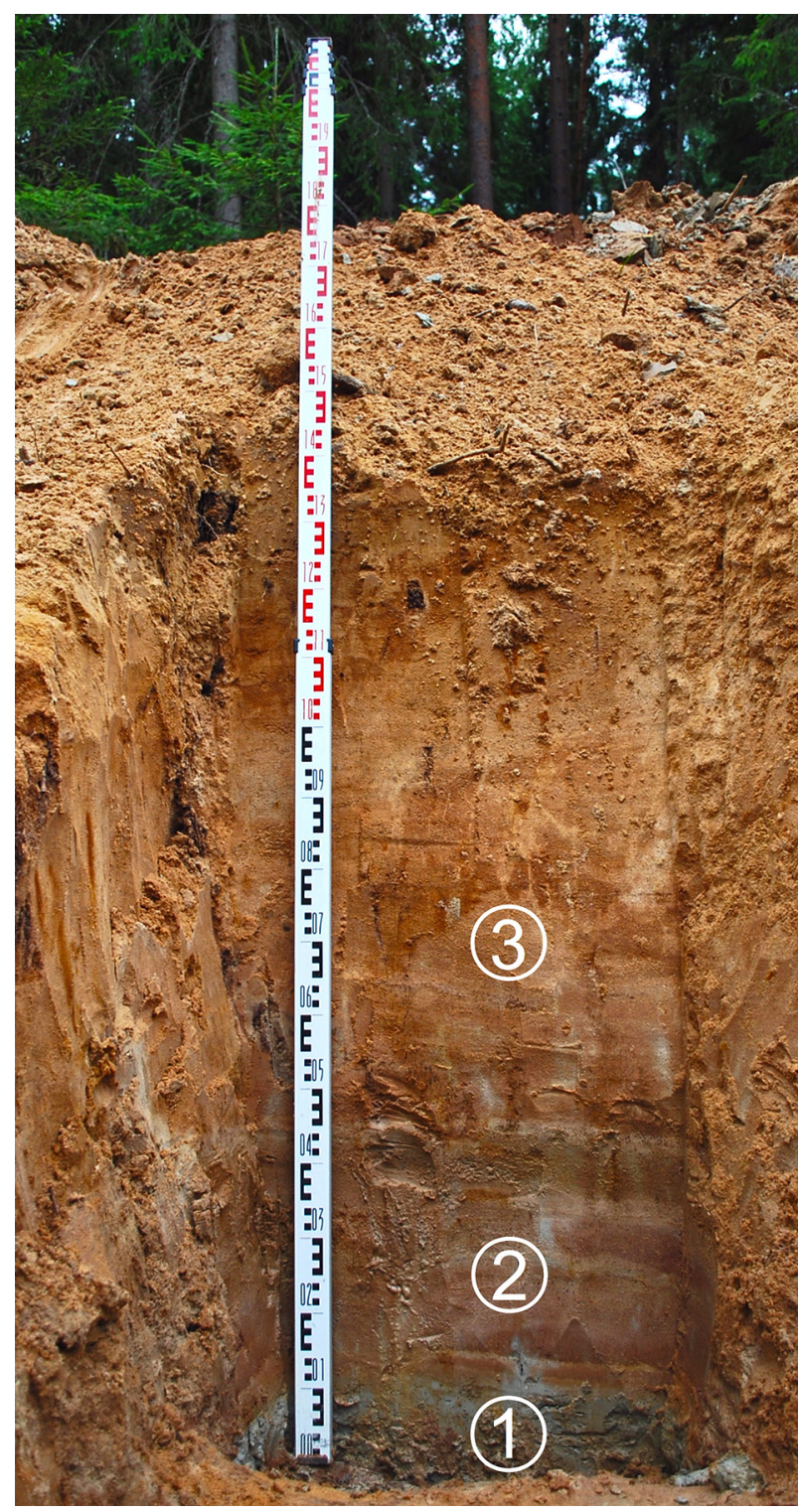

Fig. 3. General view of the Mielupite section: 1 - glaciolacustrine clays; 2 - massive (?) sand with barely visible lamination; 3 - massive sand with slightly visible semi-horizontal/translatent lamination and deformation. 


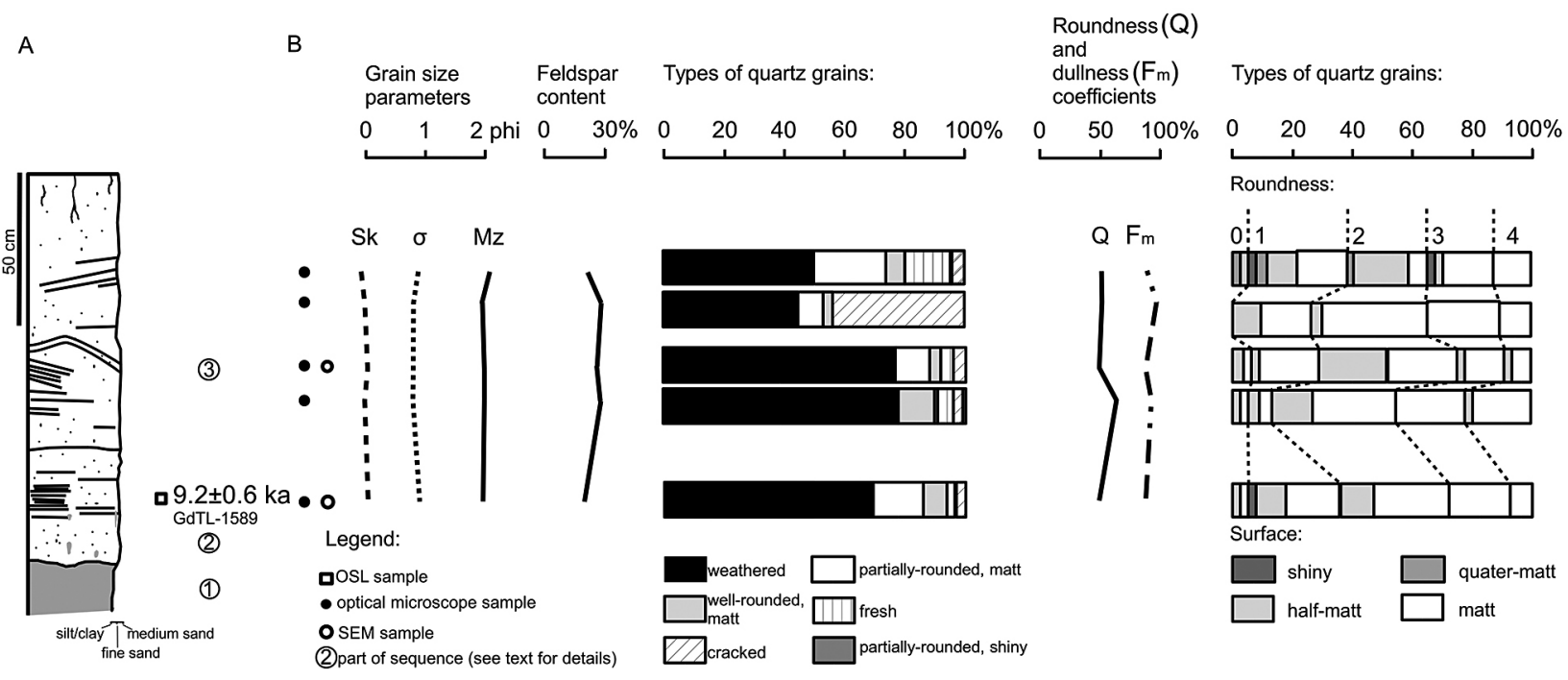

Fig. 4. A - log of sedimentary succession of the Mielupīte section with details on OSL age; B - results of grain size analyses (Sk = skewness, $\sigma=$ sorting, $\mathrm{Mz}=$ mean grain size), feldspar contribution and types of quartz grains (following methodology of Cailleux (1942) as modified by Mycielska-Dowgiałło \& Woronko (1998) and Velichko \& Timirieva (1995), respectively) observed in the section studied.

yellowish-grey sand (2 in Figs 3, 4A); the top part of section consists of massive greyish-brown sand with traces of soil processes - bleaching and enrichment in Fe III oxide through illuviation and bioturbation, as well as deformation structures (3 in Figs. 3, 4A). The granulometric composition of the sandy part of the section shows little variation in the mean $(\mathrm{Mz})$ values - they are between 1.9 and 2.1 phi (Fig. 4B). Mostly medium-grained sand prevails; however, in the topmost part of the section sand is fine. Deposits are moderately sorted with standard deviations $(\sigma)$ in the range of 0.8 to 0.85 phi. The skewness values (Sk) of most sands are symmetrical and range from -0.03 to 0.07 . Only in the uppermost part of the profile is skewness negative $(S k=-0.12$; see Fig. $4 \mathrm{~B})$. The cumulative curves are presented by a single segment with a differently sized subpopulation. On the frequency curve of grain size distribution, all samples are bimodal (Fig. 5).

The grain surface analysis shows that a group of grains with a very intensively weathered surface prevails - its share varies between 27 and 56 per cent (Fig. 4B). In the 1.1-m sample, where the amount of weathered grains is the smallest, they are accompanied with cracked grains (44 per cent). Weathered grains are followed by partially rounded grains with a matt surface (15-31 per cent). In a similar amount occur well-rounded matt grains (6-13 per cent) and grains with sharp edges (1-14 per cent). Grains with shiny surfaces are in the minority (partially rounded between 0 and 4 per cent, and well-rounded up to 1 per cent).

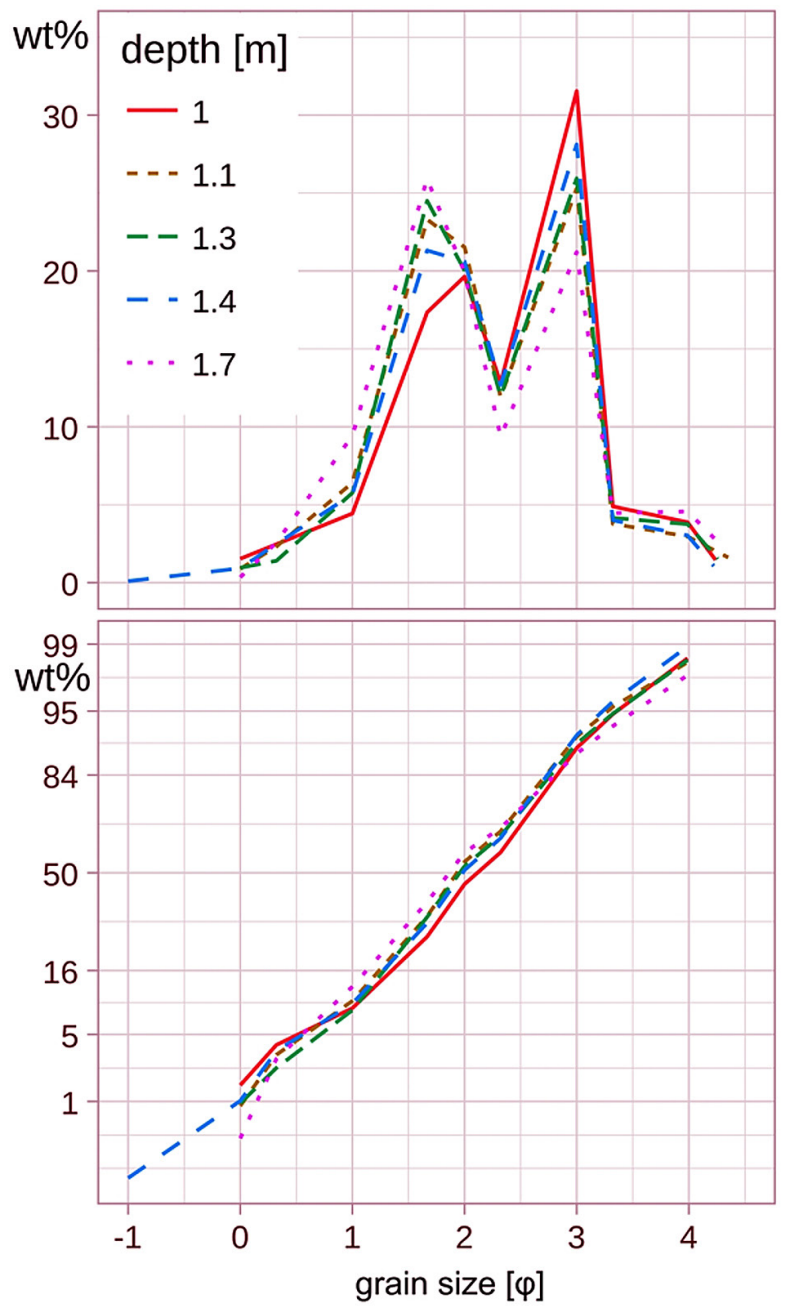

Fig. 5. Frequency (upper) and cumulative (lower) curves of sediments studied. 


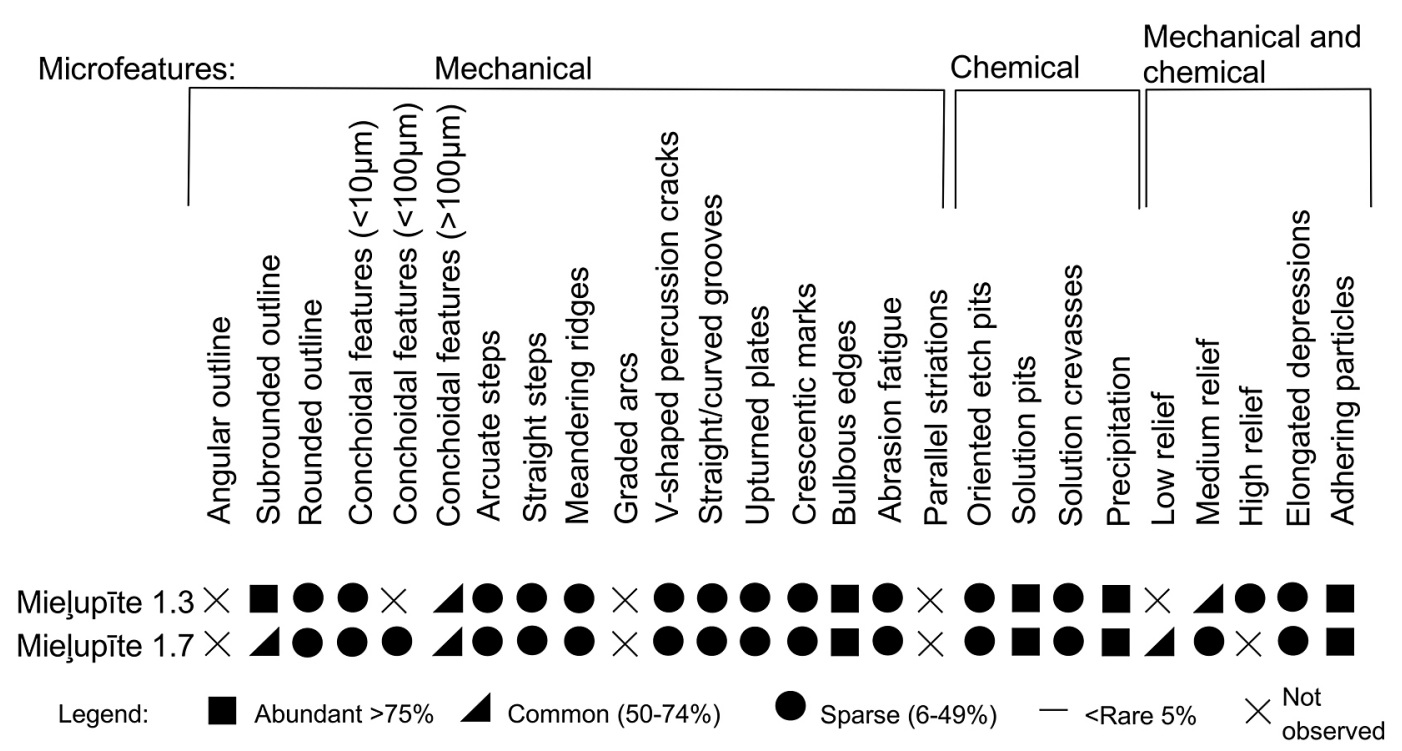

Fig. 6. Types of microtextures observed in the section studied.

The $>1.0 \mathrm{~mm}$ fraction is dominated by matt quartz grains with variable roundness (Fig. 4B). The first, second, third and fourth groups of roundness vary from 4-20, 6-30, 12-24 and 8-20 per cent, respectively. These are followed by the half-matt type of grains from the first and second roundness group (2-12 and 4-24 per cent, respectively). Quarter-matt and shiny quartz grains are in the minority. All roundness groups occur; this results in a roundness coefficient (Q) between 49 and 62 per cent. Subsequently, the dullness (mattness) coefficient (Fm) is between 85 and 94 per cent, meaning that most grains have a matt surface.

The SEM imagery of the $0.8-1.0 \mathrm{~mm}$ fraction reveals that most grains (72-75 per cent) cluster with subangular shape group (Figs 6, 7A). Rounded grains (Fig. 7B) with bulbous edges (Fig. 7C) make up around 25 per cent of the total amount of grains. Among microfeatures of mechanical origin, the large $(>100 \mu \mathrm{m})$ conchoidal fractures (Fig. 7D) are common (Fig. 6). Smaller $(10-100 \mu \mathrm{m}$ and $<10$ $\mu \mathrm{m})$ conchoidal fractures, arcuate and straight steps (Fig. 7E), V-shaped marks (Fig. 7F), straight/curved grooves and crescentic marks occur sparsely (Fig. 6). Features of chemical origin (Figs 6, 7F) are represented by solution pits (abundant), crevasses (sparse) and oriented etched pits (sparse). Additionally, all grains are precipitated to various degrees; whereas on some grains precipitation covers the entire surface (Fig. 7G), on others it occurs only in depressions (Fig. 7H). Lastly, adhering particles are present on the surface of almost all grains (Figs 6, 7F).

Using the high-stress/percussion/polygenetic approach suggested by Sweet and Soreghan (2010), the last fractures predominate in samples exam- ined, varying between 49 and 56 per cent (depths 1.3 and $1.7 \mathrm{~m}$, respectively). This is followed by the percussion group, up to 33 and 37 per cent. The group of high-stress fractures seems to remain in minority between 11 and 14 per cent.

Given the $0.8-1.0 \mathrm{~mm}$ fraction mineral composition, quartz prevails in all samples, its content varying between 66 and 76 per cent. Significant is also the presence of feldspar (20-29 per cent; Fig. 4B). This is followed by a less significant amount of lithic particles (1-5 per cent).

The equivalent dose $\left(\mathrm{D}_{\mathrm{e}}\right)$ determined is $14.5 \pm 0.8$, which corresponds to the luminescence age of 9.2 $\pm 0.6 \mathrm{ka}$ (Table 1). Present-day water-content value equals $17 \pm 5$ per cent and, considering water content of saturated sediments, a life-time burial water-content of $18 \pm 4$ per cent was established. The radionuclide concentration makes up $11.95 \pm 0.25$, the total dose rate being $1.56 \pm 0.06 \mathrm{~Gy} / \mathrm{ka}$.

\section{Discussion}

\subsection{What does the aeolian-glaciolacustrine contact look like?}

Deposits of massive structure and horizontal lamination suggest that two alternating processes were responsible (Fig. 8). These are deposition by saltation or surface traction presumably under dry conditions, which resulted in horizontally laminated strata, and deposition under moist conditions (= massive strata). Such a pattern is well known in aeolian sequences, having been observed elsewhere 


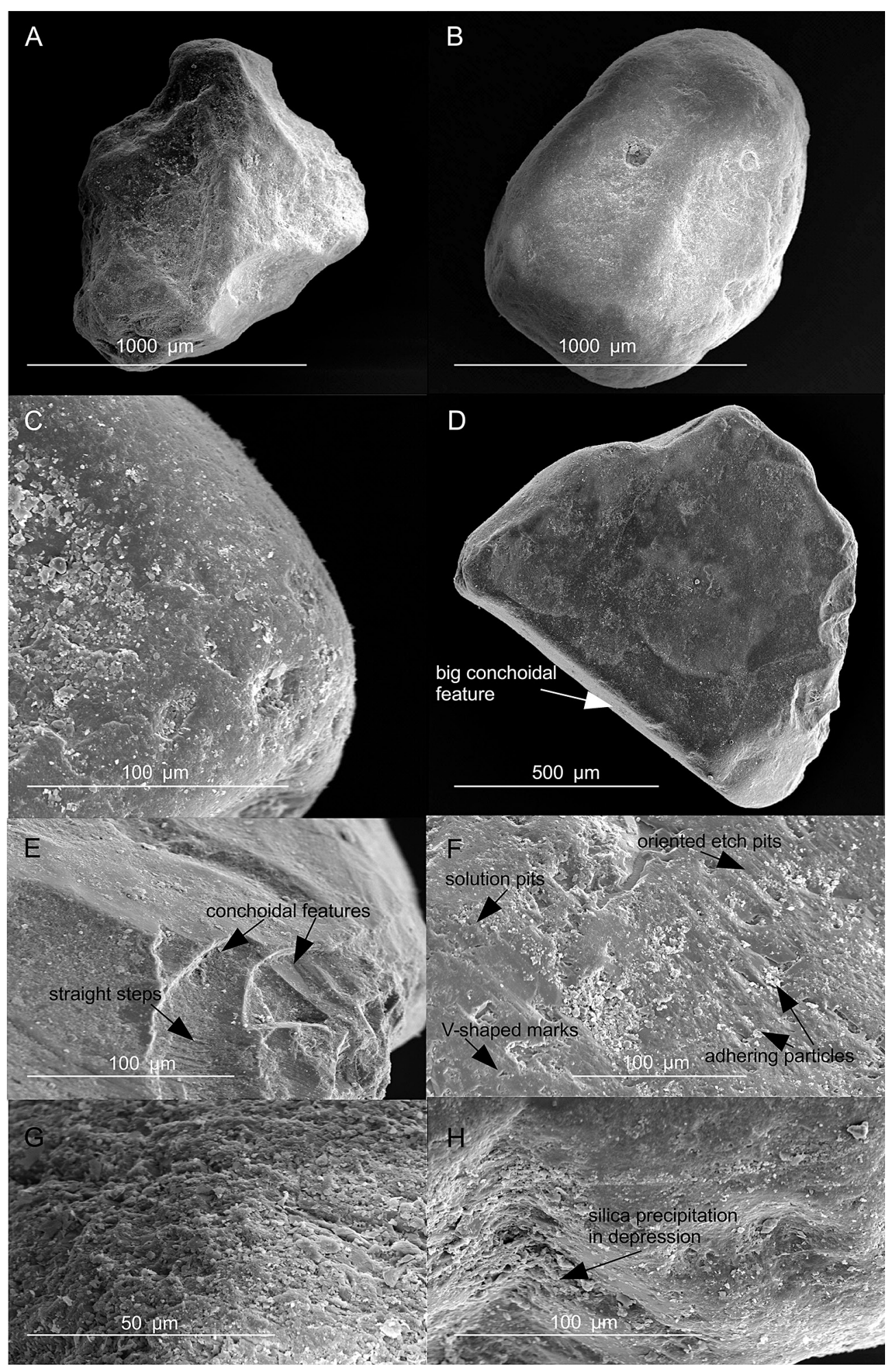

Fig. 7. Micrographs of quartz grains: A - subangular grain; B - rounded grain; C - bulbous edge; D - cracked grain with large and "old" conchoidal fracture; E - a series of conchoidal fractures with straight steps; F - grain surface with V-shaped percussion marks, pits, oriented etch pits and adhering particles; G - grain entirely covered by silica precipitation; $\mathrm{H}$ - silica precipitation concentrated in grain depression.

(Kasse et al., 2003; Kolstrup, 2007; Kalińska-Nartiša \& Nartišs, 2016b; Zieliński et al., 2016), and means that sediment could be deposited when snow melt- ed and deflation was hampered (Kolstrup, 1986). The Mielsupite site, however, possibly emerged as an up to 7-m-tall island above the water level of the 
Table 1. Summary of radionuclide concentrations, total dose rates $\left(D_{r}\right)$, equivalent doses $\left(D_{e}\right)$ and quartz OSL age: $n=$

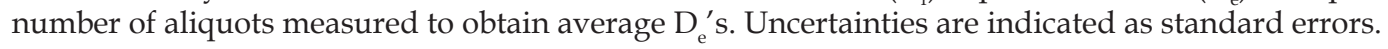

\begin{tabular}{cccccccccc}
\hline Field ID & $\begin{array}{c}\text { Laboratory } \\
\text { ID }\end{array}$ & $\begin{array}{c}238 \mathrm{U} \\
(\mathrm{Bq} / \mathrm{kg})\end{array}$ & $\begin{array}{c}232 \mathrm{Th} \\
(\mathrm{Bq} / \mathrm{kg})\end{array}$ & $\begin{array}{c}40 \mathrm{~K} \\
(\mathrm{~Bq} / \mathrm{kg})\end{array}$ & $\begin{array}{c}\text { Total dose rate } \\
(\mathrm{Gy} / \mathrm{ka})\end{array}$ & $\begin{array}{c}\text { Water } \\
\text { content } \\
(\%)\end{array}$ & $\begin{array}{c}\mathrm{n} \\
\text { OSL De } \\
(\mathrm{Gy})\end{array}$ & $\begin{array}{c}\text { OSL age } \\
(\mathrm{ka})\end{array}$ \\
Miel̦upite & GdTL-1589 & $7.65 \pm 0.15$ & $11.95 \pm 0.25$ & $399 \pm 11$ & $1.56 \pm 0.06$ & $18 \pm 4$ & 14 & $14.1 \pm 0.8$ & $9.2 \pm 0.6$ \\
\hline
\end{tabular}

ice-dammed lake; such moist/dry conditions may be responsible for the observed sedimentary structures. The translatent strata occur occasionally only in the upper part of the section studied (3 in Fig. 3), their origin indicates an accumulation on a dry substrate (Mountney, 2012) by migrating wind ripples (Hunter, 1977; Rodríguez-López et al., 2008).

By applying grain size parameters it is possible to diagnose particular sedimentary environments as the strength of the transporting environment $(\mathrm{Mz})$, the changeability and dynamics of transport $(\sigma)$ and the variation in the strength of the transporting environment (Folk, 1971; Folk \& Ward, 1957; Visher, 1969; Zhang \& Dong, 2015). In an aeolian environment, sediment grain size distribution controls creep, saltation and suspension in landform (dune) formation and development (Zhang \& Dong, 2015). Since medium- and fine-grained and moderately sorted sands prevail at the site investigated, and the range of these values is rather narrow with a single-segmented cumulative curves (Fig. 5), an aeolian environment may be proposed as the preliminary setting (Fig. 6; Mycielska-Dowgiałło \& Ludwikowska-Kędzia, 2011; Zieliński et al., 2015). When tracing regional trends, similar grain size distributions of aeolian deposits occur both at adjacent localities in Estonia and Lithuania; glaciolacustrine sands tend to be slightly finer and better sorted (Kalińska-Nartiša et al., 2015a, b). Also following the formula that allows to distinguish conventionally between the aeolian component in a sequence of palaeolacustrine sediments as proposed by Zhang et al. (2008), sediments at Mielupipite appear to be aeolian in origin. Grain size distribution alone, however, is not typical of any particular setting, and can occur both in aeolian and glaciolacustrine settings.

Sediments studied are composed of quartzofeldspatic sands, in which feldspar and lithic fragments constitute up to 30 per cent of the general composition, and presumably reflect the surrounding immature glaciolacustrine and glacial source. However, such pattern disagrees with properties of well-defined aeolian sediments, which reveal at least 95 per cent of quartz in their composition (Pettijohn et al., 1972; Muhs, 2004). In doing so, our results suggest that aeolian processes did not trans- form the sediment significantly. Such a trend has also been observed elsewhere in the Baltic States (Kalińska-Nartiša et al., 2016), and is additionally supported by the only limited number of grains produced in an aeolian environment (see below).

Among all types of quartz grains in the present study, those with weathered surface are of great importance. They result from dissolution in situ or/and silica precipitation and were referred to as "other" (Woronko et al., 2015). However, our results show that these grains have rather non-abraded or only slightly rounded outlines and could therefore be similar to 'non-worn' grains with a dull surface as observed by Ritchot \& Cailleux (1971). Similar grains, termed "frost-fissured", were noted by Velichko \& Timirieva (1995) and Ba$\log$ et al. (2014); these were subjected to periglacial conditions and contemporary climatic impact, respectively. In SEM, these grains are rather subangular with an intense precipitation on their surface (e.g., Fig. 7G). This grain outline does not stand alone within the sediments studied, but yields a significant concentration at numerous localities in the Baltic States (Kalińska \& Nartišs, 2014). This concentration is likely due to (1) a seasonal freezing or/and action of fluids that can lead to grain splitting (Velichko \& Timirieva, 1995) in a periglacial environment (Woronko et al., 2015) and/ or (2) a possible inheritance from corroded and deformed quartz outlines, occasionally fractured and cracked, of the carbonate-cemented siliciclastic rocks of the Devonian Baltic Basin (Kleesment et al., 2012). The deformations present in the upper part of the section (Fig. 4) could be of cryogenic origin, thus supporting the scenario of seasonal freeze/thaw impact. However, there are no data on cryogenic/periglacial structures in the lowland to strengthen this interpretation.

When possible scenarios are considered, the sedimentary sequence at Miel̦upite must be positioned in cold and dry periglacial climatic conditions in the foreland of the Linkuva ice-marginal zone, where freeze/thaw processes interplayed with both limited deflation and deposition on the melting snow. Material may have been delivered from numerous directions/sources, since dunes in this area are largely irregular (Fig. 2). Multi-sourcing may also 
be apparent from grain size distribution; two fractions prevail in the sediments analysed (Fig. 5). Under such conditions a number of weathered grains were produced in combination with a limited number of matt-surface grains of various rounding degrees. The latter grain outline reveals either (1) a collision of grains and their abrasion under aeolian conditions, thus increasing the average degree of rounding (Refaat \& Hamdan, 2015), or (2) chemical solution and redeposition of silica that can lead to rounding of quartz grains (Kuenen \& Peredok, 1962). The first aeolian scenario is largely supported in our study by a presence of bulbous edges (Figs. 6, 7C), abrasion fatigue and elongated, smoothed-over depressions; these features are commonly interpreted to reflect saltation phases (Vos et al., 2014), indicative of intense aeolian processes. Nevertheless, aeolian grains of the $0.8-1.0 \mathrm{~mm}$ fraction decrease towards the top of the section (except for the uppermost sample); this variation may be a relict feature inherited from potential source sediments, as observed by Mahaney et al. (2000).

The content of matt-type grains seems to increase towards the $>1.0 \mathrm{~mm}$ fraction; occasionally, these grains occur exclusively in most of the roundness classes. This means that not only grains of the highest roundness degree ( $3 \mathrm{rd}-4$ th classes), but also non-abraded grains from the 0 and possibly the 1 st classes have a matt surface. These classes possibly correspond with the grains with intense precipitation as observed in the $0.8-1.0 \mathrm{~mm}$ fraction; their share, however, seems to be less significant.

Although cracked grains contribute to some extent in all samples studied, there is no apparent explanation for the high proportion of these grains in sample from a depth of $1.1 \mathrm{~m}$. Considering their occurrence to be due to grain breakage and crushing in high-energy subaqueous (Helland \& Holmes, 1997) and glacial environments (Vos et al., 2014), the cracked grains are possibly of short-transportation distance and, therefore, originate from the adjacent moraine-like area. Similarly, the SEM results exhibit that more than half of the grains analysed reveal the largest $(>100 \mu \mathrm{m})$ conchoidal features, supporting a collision between grains. The collision cannot, however, have been under high shear stress, because only a minor percentage of high-stress microtextures has been observed in the investigated samples. Mechanical microfeatures, such as conchoidal fractures, steps, grooves or crescentic gouges, are imprinted on quartz grains from Mielsupite and, combined with an admixture of grain shapes, can be diagnosed as an imprint of glacial (Krinsley \& Doornkamp, 1973; Mahaney, 2002; Mahaney et al., 2001; Mahaney \& Kalm, 1995) or/and glaciolacus-

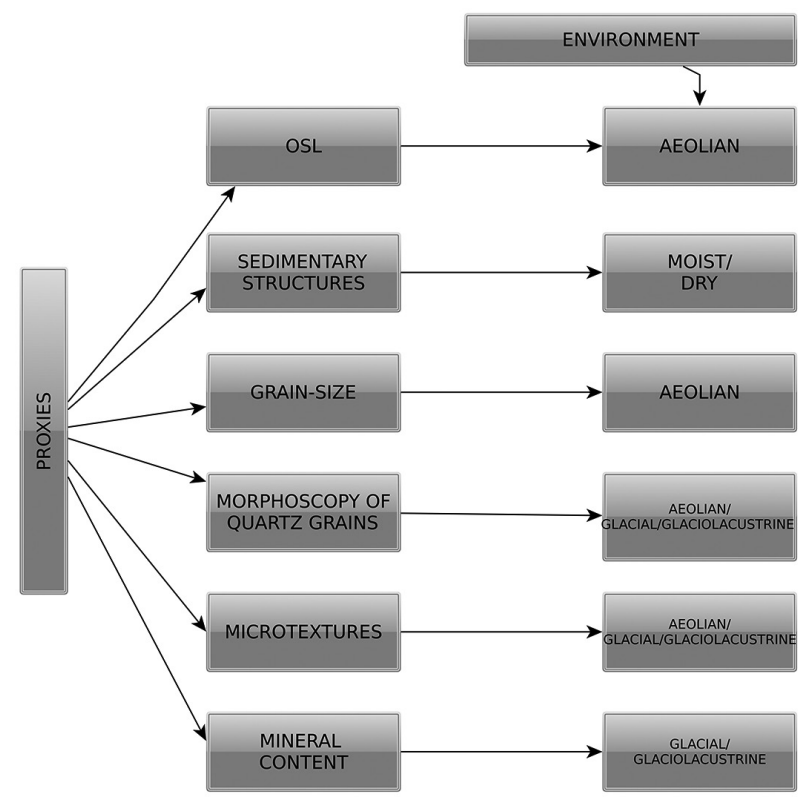

Fig. 8. Aeolian or glaciolacustrine record? Proxies used in the present study and their potential sedimentary environment.

trine environment (Narayana et al., 2010). These two types of environment are volumetrically significant, having an impact on the facies studied (Fig. 8).

\subsection{When did deposition take place?}

The single available luminescence date of $9.2 \pm 0.6$ ka corresponds roughly with the Holocene cold phase known as the $9.1 \mathrm{ka}$ (Boch et al., 2009), 9.2 ka (Blockley et al., 2012) or 9.3 ka event (Rasmussen et al., 2007), which is considered to have been a widespread and significant cold climatic anomaly (Fleitmann et al., 2008), with records from numerous proxies (Axford et al., 2009; Lang et al., 2010; Yu et al., 2010; Young et al., 2013; Brynjólfsson et al., 2015; Lord et al., 2015). This is also consistent with the increased input of terrigeneous matter in lacustrine sediments, which could be related to the decay of vegetation and soil layer as found occasionally in the region (Gryguc et al., 2013; Saarse, 2015) and which coincides with a gradual temperature decrease in the northern Baltic region (Heikkilä \& Seppä, 2010; Veski et al., 2004, 2015). To date, this cold event has not been detected in the organic record of Latvia (Stivrins et al., 2014, 2015); thus it probably did not a great impact on the increase of aeolian activity. This is in contrast to central and western Europe, where aeolian activity of a similar time span took place (Tolksdorf \& Kaiser, 2012; Zieliński et al., 2015). In Latvia, the early Holocene aeolian depo- 
sition has been dated at $9.1 \pm 2.3 \mathrm{ka}$ and $9.4 \pm 1.9 \mathrm{ka}$ in the uppermost part of dunes distributed on the glaciolacustrine sediment of the ice-dammed lake at the localities of Dores \& Bērzi, respectively (Nartišs et al., 2009), $45 \mathrm{~km}$ northwest of the section studied here. However, this luminescence date suffers from a large error range (>20 per cent) and thus remains questionable. Additionally, a single date from the interdune area at Bērzi yielded a date of $8.5 \pm 0.5 \mathrm{ka}$ (Kalińska-Nartiša et al., 2016) and, although correlated rather with the cold $8.2 \mathrm{ka}$ event (Rasmussen et al., 2007), it does match the error range based on results from the present study.

The luminescence age obtained significantly postdates the minimum age of the Linkuva ice-marginal zone with its minimum ${ }^{10} \mathrm{Be}$ ages between 15.4 and $12.0 \mathrm{ka}$ (Rinterknecht et al., 2006). Following our earlier assumption that glaciolacustrine deposition was temporarily linked with this ice-marginal zone, a gap of 2.8-6.2 ka possibly existed in our section, which coincides with a marked timespan of the Preboreal Oscillation, the GS-1 and GI-1 (Blockley et al., 2012). This likely suggests that the sedimentary record is not continuous. However, we have not found any sedimentary evidence such as clearly distinguishable erosional surfaces in our section. Assuming our luminescence result and the general geological situation, glaciolacustrine deposition occurred between 15.4 and $12.0 \mathrm{ka}$. A hiatus means no data on events until $9.2 \mathrm{ka}$, when aeolian deposition started and further possibly continued throughout the Atlantic, since large dunes within areas of high dune concentration were active elsewhere in the adjacent lowland of northern Vidzeme (Nartišs et al., 2009). However, such a scenario does not match the sedimentary features documented, in which an aeolian-periglacial factor under cold climatic conditions in the foreland of the Linkuva ice-marginal zone is emphasised. In other words, aeolian processes were possibly enhanced directly (without a pause) after drainage of the Middle Gauja ice-dammed lake and drying of sandy/silty surfaces, thus having been prone to wind transportation. Both scenarios can be equally valid; to resolve this future work at higher OSL resolution is required.

\subsection{To what extent can the aeolian signature be distinguished?}

Our preliminary proxies help decipher the aeolian component from the sedimentary record and offer a better understanding of sediment origin itself. Importantly, the number of samples for age determi- nation is very limited and can only serve as the first step towards the establishment of a temporal frame.

Having only the OSL result allows us to conclude that sediments at Mielupite represent exclusively the Holocene aeolian signature of dune complexes in the Middle Gauja Lowland. However, only a single date from the section might be a random result that is in need of careful interpretation, although luminescence dating is believed to provide a meaningful age control (Forman \& Waters, 2016). Sedimentary characteristics are, in contrast, less unequivocal (Fig. 8).

Analysis of quartz grains reveals a predominance of periglacial- and aeolian-type quartz grains, and thus rather signifies aeolian conditions during deposition. Such environment is also apparent from grain-size parameters. Less mechanically resistant feldsphatic elements in the sediments do not represent, in contrast, a typical aeolian record as observed in, for example, aeolian settings of multi-reworking, having been derived from pre-existing recycled sediments (Howari et al., 2007; Sweet \& Soreghan, 2010; Hamdan et al., 2015; Woronko et al., 2015). However, a similar immature mineral record has been observed elsewhere in the Baltic States (Kalińska-Nartiša et al., 2016). Also sedimentary structures are attributable to either dry or moist depositional conditions, which might occur in aeolian settings. It is apparent from the present study that the sedimentary record at Mielupite was influenced by numerous factors. That said, additional work is needed for a better understanding of the regional palaeoenvironment.

\section{Final remarks}

Our set of new sedimentary data, combined with a single geochronological proxy, provides a signature of the glaciolacustrine-aeolian sediment contact at Mielupīte, Middle Gauja Lowland, northeast Latvia. A matter of debate is whether the sediments studied were deposited under glaciolacustrine or aeolian conditions and when this deposition took place. Most proxies indicate aeolian conditions and this is greatly supported by (1) a small variability of grain size parameters, (2) a significant input of silica precipitated periglacial-type grains and matt-surface grains of various rounding degrees with bulbous edges in all observed grains, occasionally associated with elongated smoothed-over depressions, and (3) dry-moist depositional condtions. The mineral composition is not as unequivocal and points at imprint of a glacial/glaciolacustrine environment, 
which has, however, been observed in aeolian settings in the region.

Sediments were deposited at $9.2 \pm 0.6 \mathrm{ka}$, which correlates with a widespread and significant cold Holocene climatic anomaly, and significantly postdates the minimum age of the Linkuva ice-marginal zone with ${ }^{10} \mathrm{Be}$ ages between 15.4 and $12.0 \mathrm{ka}$. This means that deposition did not take place directly after deglaciation and that a hiatus of 2.8-6.2 ka exists in the section studied. However, sedimentary evidence supports rather a scenario, where aeolian processes were possibly enhanced directly after drainage of the Middle Gauja ice-dammed lake. Clearly, more future work is required to resolve this issue.

\section{Acknowledgements}

We thank Dr Normunds Stivrinšs (University of Helsinki, Finland) for valuable discussion, Ivars Celinšs (University of Latvia) and Alexander Gorlach (University of Tartu, Estonia) for their help during fieldwork and two anonymous reviewers for valuable comments that improved our manuscript. This research was supported by research funding of University of Latvia (to M. Nartišs), by the Postdoctoral Research Grant ERMOS (FP7 Marie Curie Co-fund the 'People programme') 'Age and climatic signature of coversands deposits distributed on glaciolacustrine basins along the Scandinavian Ice Sheet margin southeast of the Baltic Sea', and by SunGIS SIA (to E. Kalińska-Nartiša).

\section{References}

Alexanderson, H. \& Henriksen, M., 2015. A short-lived aeolian event during the Early Holocene in southeastern Norway. Quaternary Geochronology 30, 175-180.

An, F., Ma, H., Wei, H. \& Lai, Z., 2012. Distinguishing aeolian signature from lacustrine sediments of the Qaidam Basin in northeastern Qinghai-Tibetan Plateau and its palaeoclimatic implications. Aeolian Research 4, 17-30.

Antoine, P., Catt, J., Lautridou, J.-P. \& Sommé, J., 2003. The loess and coversands of northern France and southern England. Journal of Quaternary Science 18, 309-318.

Axford, Y., Briner, J.P., Miller, G.H. \& Francis, D.R., 2009. Paleoecological evidence for abrupt cold reversals during peak Holocene warmth on Baffin Island, Arctic Canada. Quaternary Research 71, 142-149.

Balog, K., Kalmár, J., Kuti, L., Szabó, A. \& Tóth, T., 2014. Sand grain mineralogy and morphology under forest and grassland/arable fields in Eastern Hungary. Agrokémia és Talajtan 63, 29-38.

Björck, S. \& Clemmensen, L.B., 2004. Aeolian sediment in raised bog deposits, Halland, SW Sweden: a new proxy record of Holocene winter storminess variation in southern Scandinavia. The Holocene 14, 677-688.
Blockley, S.P.E., Lane, C.S., Hardiman, M., Rasmussen, S.O., Seierstad, I.K., Steffensen, J.P., Svensson, A., Lotter, A.F., Turney, C.S.M. \& Bronk Ramsey, C., 2012. Synchronisation of palaeoenvironmental records over the last 60,000 years, and an extended INTIMATE event stratigraphy to 48,000 b2k. Quaternary Science Reviews 36, 2-10.

Blott, S.J. \& Pye, K., 2012. Particle size scales and classification of sediment types based on particle size distributions: Review and recommended procedures. Sedimentology 59, 2071-2096.

Boch, R., Spötl, C. \& Kramers, J., 2009. High-resolution isotope records of early Holocene rapid climate change from two coeval stalagmites of Katerloch Cave, Austria. Quaternary Science Reviews 28, 2527-2538.

Böse, M., Lüthgens, C., Lee, J.R. \& Rose, J., 2012. Quaternary glaciations of northern Europe. Quaternary Science Reviews 44, 1-25.

Brynjólfsson, S., Schomacker, A., Ingólfsson, Ó. \& Keiding, J.K., 2015. Cosmogenic ${ }^{36} \mathrm{Cl}$ exposure ages reveal a 9.3 ka BP glacier advance and the Late Weichselian-Early Holocene glacial history of the Drangajökull region, northwest Iceland. Quaternary Science Reviews 126, 140-157.

Cailleux, A., 1942. Les actiones éoliennes périglaciaires en Europe. Mémoires de la Société Géologique de France 41, $1-176$.

Celinš̌, I., Karušs, J., Kalińska-Nartiša, E. \& Nartišs, M., 2014. Morphology, internal structure and texture of inland dunes at the Smilškalni site, Middle Gauja Lowland. [In:] V. Zelčs \& M. Nartišs (Eds), Late Quaternary Terrestrial Processes, Sediments and History: From Glacial to Postglacial Environments. Excursion Guide and Abstracts of the INQUA Peribaltic Working Group Meeting and Field Excursion in Eastern and Central Latvia. University of Latvia, Rīga, 42-46.

Crombe, P., Van Strydonck, M., Boudin, M., Van den Brande, T., Derese, C., Vandenberghe, D.A.G., Van den Haute, P., Verniers, J., Gelorini, V., Boss, J.A.A., Verbruggen, F., Antrop, M., Bats, M., Bourgeois, J., De Reu, J., De Maeyer, P., De Smedt, P., Finke, P.A., Van Meirvenne, M. \& Zwertvaegher, A., 2012. Absolute dating (14C and OSL) of the formation of coversand ridges by prehistoric hunter-gatherers in NW Belgium. Radiocarbon 54, 715-726.

Fleitmann, D., Mudelsee, M., Burns, S.J., Bradley, R.S., Kramers, J. \& Matter, A., 2008. Evidence for a widespread climatic anomaly at around 9.2 ka before present. Paleoceanography 23, 1-6.

Folk, R.L., 1971. Longitudinal dunes of the nortwesten edge of the Simpson Desert, Northern Territory, Australia. 1. Geomorphology and grain size relationships. Sedimentology 16, 5-54.

Folk, R.L. \& Ward, W.C., 1957. Brazos River Bar: A study in the significance of grain size parameters. Journal of Sedimentary Research 27, 3-26.

Forman, S.L. \& Waters, M.R., 2016. Optically stimulated luminescence dating and the pepoling of the Americas. PaleoAmerica 2, 6-10.

Galbraith, R.F., Roberts, R.G., Laslett, G.M., Yoshida, H. \& Olley, J.M., 1999. Optical dating of single and 
multiple grains of quartz from Jinmium rock shelter, Northern Australia: Part I, Experimetal design and statistical models. Archaeometry 41, 339-364.

Gilbert, E.R., De Camargo, M.G. \& Sandrini-Neto, L., 2012. Rysgran: Grain size analysis, textural classifications and distribution of unconsolidated sediments. R package version 2.0 https://CRAN.R-project.org/package $=$ rysgran

Gryguc, G., Kisielienė, D., Stančikaitè, M., Šeirienė, V., Skuratovič, Ž., Vaitkevičius, V., \& Gaidamavičius, A., 2013. Holocene sediment record from Briaunis palaeolake, Eastern Lithuania: history of sedimentary environment and vegetation dynamics. Baltica 26, 121-136.

Hamdan, M.A., Refaat, A.A., Anwar, E.A., Shallaly, N.A. \& Hamdan, M.A., 2015. Mineralogy and grain morphology of the aeolian dune sand of Toshka area, southeastern Western Desert, Egypt. Aeolian Research $17,243-254$.

Heikkilä, M. \& Seppä, H., 2010. Holocene climate dynamics in Latvia, eastern Baltic region: a pollen-based summer temperature reconstruction and regional comparison. Boreas 39, 705-719.

Helland, P.E. \& Holmes, M.A., 1997. Surface textural analysis of quartz sand grains from ODP Site 918 off the southeast coast of Greenland suggests glaciation of southern Greenland at 11 Ma. Palaeogeography Palaeoclimatology Palaeoecology 135, 109-121.

Howari, F.M., Baghdady, A. \& Goodell, P.C., 2007. Mineralogical and gemorphological characterization of sand dunes in the eastern part of United Arab Emirates using orbital remote sensing integrated with field investigations. Geomorphology 83, 67-81.

Hunter, R.E., 1977. Basic types of stratification in small eolian dunes. Sedimentology 24, 361-387.

Juškevičs, V. \& Skrebels, J., 2002. Quaternary Deposits. Sheets 44, 45, 54 (Alūksne, Vilakaka, Valka), [In:] O.P. Āboltinš̌ \& A. Brangulis (Eds), Geological Map of Latvia. Scale 1:200 000. Valsts ǵeoloǵijas dienests, Rīga.

Kalińska, E. \& Nartišs, M., 2014. Pleistocene and Holocene aeolian sediments of different location and geological history: A new insight from rounding and frosting of quartz grains. Quaternary International 328-329, 311-322.

Kalińska-Nartiša, E. \& Nartišs, M., 2016a. The fan-like forms in the southern margin of the Mazovian Lowland area (Central Poland): a new high-resolution textural-timing study. International Journal of Earth Sciences 105, 885-903.

Kalińska-Nartiša, E. \& Nartišs, M., 2016b. Sandy fan-like forms in the central-eastern Mazovian Lowland (Central Poland): textural record and chronology. Geografiska Annaler, Series A, Physical Geography 98, 111-127.

Kalińska-Nartiša, E., Soms, J., Strode, S. \& Nartišs, M., 2014. Inland dune field near Daugavpils, East-Latvian Lowland. [In:] V. Zelčs \& M. Nartišs (Eds.), Late Quaternary Terrestrial Processes, Sediments and History: From Glacial to Postglacial Environments. Excursion Guide and Abstracts of the INQUA Peribaltic Working Group Meeting and Field Excursion in Eastern and Central Latvia. University of Latvia, Rīga, 77-80.
Kalińska-Nartiša, E., Nartišs, M., Thiel, C., Buylaert, J.-P. \& Murray, A.S., 2015a. Late-glacial to Holocene aeolian deposition in northeastern Europe - The timing of sedimentation at the Iisaku site (NE Estonia). Quaternary International 357, 70-81.

Kalińska-Nartiša, E., Thiel, C., Nartišs, M., Buylaert, J.-P. \& Murray, A.S., 2015b. Age and sedimentary record of inland aeolian sediments in Lithuania, NE European Sand Belt. Quaternary Research 84, 82-95.

Kalińska-Nartiša, E., Thiel, C., Nartišs, M., Buylaert, J.P. \& Murray, A.S., 2016. The north-eastern aeolian "European Sand Belt" as potential record of environmental changes: a case study from Eastern Latvia and Southern Estonia. Aeolian Research 22, 59-72.

Kasse, C., Vandenberghe, J., van Huissteden, J., Bohncke, S.J.P. \& Bos, J.A.A., 2003. Sensitivity of Weichselian fluvial systems to climate change (Nochten mine, eastern Germany). Quaternary Science Reviews 22, 2141-2156.

Käyhkö, J.A., Worsley, P., Pye, K. \& Clarke, M.L., 1999. A revised chronology for aeolian activity in subarctic Fennoscandia during the Holocene. The Holocene 9, 195-205.

Kleesment, A., Kirsimäe, K., Martma, T., Shogenova, A., Urtson, K. \& Shogenov, K., 2012. Linkage of diagenesis to depositional environments and stratigraphy in the northern part of the Baltic basin. Estonian Journal of Earth Sciences 61, 15-32.

Kolstrup, E., 1986. Reappraisal of the upper Weichselian periglacial environment from Danish frost wedge casts. Palaeogeography Palaeoclimatology Palaeoecology 56, 237-249.

Kolstrup, E., 2007. Lateglacial older and younger coversand in northwest Europe: chronology and relation to climate and vegetation. Boreas 36, 65-75.

Krajcarz, M.T., Cyrek, K., Krajcarz, M., Mroczek, P., Sudoł, M., Szymanek, M., Tomek, T., \& Madeyska, T., 2016. Loess in a cave: Lithostratigraphic and correlative value of loess and loess-like layers in caves from the Kraków-Czestochowa Upland (Poland). Quaternary International 399, 13-30.

Krinsley, D.H. \& Doornkamp, J.C., 1973. Atlas of Quartz Sand Surface Textures, Cambridge University Press, Oxford, 93 pp.

Kuenen, P.H. \& Peredok, W.G., 1962. Experimental Abrasion 5. Frosting and Defrosting of Quartz Grains. Journal of Geology 70, 648-658.

Küster, M., Fülling, A., Kaiser, K. \& Ulrich, J., 2014. Aeolian sands and buried soils in the Mecklenburg Lake District, NE Germany: Holocene land-use history and pedo-geomorphic response. Geomorphology 211, 64-76.

Lang, B., Bedford, A., Brooks, S., Jones, R., Richardson, N., Birks, H. \& Marshall, J., 2010. Early-Holocene temperature variability inferred from chironomid assemblages at Hawes Water, northwest England. The Holocene 20, 943-954.

Lord, T., Thorp, J. \& Wilson, P., 2015. A wild boar dominated ungulate assemblage from an early Holocene natural pit fall trap: Cave shaft sediments in north- 
west England associated with the $9.3 \mathrm{ka}$ BP cold event. The Holocene 147-153.

Mahaney, W.C., 2002. Atlas of sand grain surface, textures and applications. Oxford University Press, Oxford, 256 pp.

Mahaney, W.C. \& Kalm, V., 1995. Scanning electron microscopy of Pleistocene tills in Estonia. Boreas 24, 13-19.

Mahaney, W.C. \& Kalm, V., 2000. Comparative scanning electron microscopy study of oriented till blocks, glacial grains and Devonian sands in Estonia and Latvia. Boreas 29, 35-51.

Mahaney, W.C., Stewart, A. \& Kalm, V., 2001. Quantification of SEM microtextures useful in sedimentary environmental discrimination. Boreas 30, 165-171.

Margielewski, W., Krąpiec, M., Jankowski, L., Urban, J. \& Zernitskaya, V., 2015. Impact of aeolian processes on peat accumulation: Late Glacial e Holocene history of the Hamernia peat bog (Roztocze region, south-eastern Poland). Quaternary International 386, 212-225.

Marks, L., 2012. Timing of the Late Vistulian (Weichselian) glacial phases in Poland. Quaternary Science Reviews 44, 81-88.

Matthews, J.A. \& Seppälä, M., 2013. Holocene environmental change in subarctic aeolian dune fields: The chronology of sand dune re-activation events in relation to forest fires, palaeosol development and climatic variations in Finnish Lapland. The Holocene 24, 149-164.

Mountney, N.P., 2012. A stratigraphic model to account for complexity in aeolian dune and interdune successions. Sedimentology 59, 964-989.

Muhs, D.R., 2004. Mineralogical maturity in dunefields of North America, Africa and Australia. Geomorphology 59, 247-269.

Murray, A.S. \& Wintle, A.G., 2000. Luminescence dating of quartz using an improved single-aliquot regenerative-dose protocol. Radiation Measurements 32, 57-73.

Mycielska-Dowgiałło, E. \& Ludwikowska-Kędzia, M., 2011. Alternative interpretations of grain-size data from Quaternary deposits. Geologos 17, 189-203.

Mycielska-Dowgiałło, E. \& Woronko, B., 1998. Analiza obtoczenia i zmatowienia powierzchni ziarn kwarcowych frakcji piaszczystej i jej wartość interpretacyjna [Rounding and frosting analysis of quartz sandgrain surfaces and their interpretative significance]. Przeglad Geologiczny 46, 1275-1281.

Narayana, A.C., Mohan, R. \& Mishra, R., 2010. Morphology and surface textures of quartz grains from freshwater lakes of McLeod Island, Larsemann Hills, East Antarctica. Current Science 99, 1420-1424.

Nartišs, M., 2014. Ice meltwater lake of Northern Vidzeme and Middle Gauja Lowlands during the Late Weichselian deglaciation. Doctoral thesis. University of Latvia, Rìga, $142 \mathrm{pp}$.

Nartišs, M., Celinšs, I., Zelčs, V. \& Dauškans, M., 2009. History of the development and palaeogeography of ice-dammed lakes and inland dunes at Seda sandy plain, North Western Vidzeme, Latvia. [In:] V. Kalm, L. Lauments \& T. Hang (Eds), Extent and Timing of the Weichselian Glaciation Southeast of the Baltic Sea:
Abstracts \& Guidebook. The INQUA Peribaltic Working Group Field Symposium in Southern Estonia and Northern Latvia. Ülikooli Kirjastus, Tartu, 79-81.

Pettijohn, F.J., Potter, P.E. \& Siever, R., 1972. Sand and Sandstones. Springer-Verlag, Cambridge, 618 pp.

Rasmussen, S.O., Vinther, B.M., Clausen, H.B. \& Andersen, K.K., 2007. Early Holocene climate oscillations recorded in three Greenland ice cores. Quaternary Science Reviews 26, 1907-1914.

Refaat, A.A. \& Hamdan, M.A., 2015. Mineralogy and grain morphology of the aeolian dune sand of Toshka area, southeastern Western Desert, Egypt. Aeolian Research 17, 243-254.

Rinterknecht, V.R., Clark, P.U., Raisbeck, G.M., Yiou, F., Bitinas, A., Brook, E.J., Marks, L., Zelcs, V., Lunkka, J.-P., Pavlovskaya, I.E., Piotrowski, J.A. \& Raukas, A., 2006. The last deglaciation of the southeastern sector of the Scandinavian ice sheet. Science 311, 1449-52.

Ritchot, G. \& Cailleux, A., 1971. Taxonomie, géomorphologie et morphoscopie de sables au Québec méridional. Cahiers de géographie du Québec 15, 423.

Rodríguez-López, J.P., Meléndez, N., de Boer, P.L. \& Soria, A.R., 2008. Aeolian sand sea development along the mid-Cretaceous western Tethyan margin (Spain): erg sedimentology and palaeoclimate implications. Sedimentology 55, 1253-1292.

Román-Sierra, J., Muñoz-Pérez, J.J. \& Navarro-Pons, M., 2013. Influence of sieving time on the efficiency and accuracy of grain-size analysis of beach and dune sands. Sedimentology 60, 1484-1497.

Roskosch, J., Tsukamoto, S., Meinsen, J., Frechen, M. \& Winsemann, J., 2012. Luminescence dating of an Upper Pleistocene alluvial fan and aeolian sandsheet complex: The Senne in the Münsterland Embayment, NW Germany. Quaternary Geochronology 10, 94-101.

Saarse, L., 2015. Cyclic sedimentation pattern in Lake Veetka, southeast Estonia: A case study. Geologos 21, 59-69.

Stivrins, N., Kalnina, L., Veski, S. \& Zeimule, S., 2014. Local and regional Holocene vegetation dynamics at two sites in eastern Latvia. Boreal Environment Research 19, 310-322.

Stivrins, N., Kolaczek, P., Reitalu, T., Seppä, H. \& Veski, S., 2015. Phytoplankton response to the environmental and climatic variability in a temperate lake over the last 14,500 years in eastern Latvia. Journal of Paleolimnology 54, 103-119.

Sweet, D.E. \& Soreghan, G.S., 2010. Application of Quartz Sand Microtextural Analysis to Infer Cold-Climate Weathering for the Equatorial Fountain Formation (Pennsylvanian-Permian, Colorado, U.S.A.). Journal of Sedimentary Research 80, 666-677.

Tate, S.E., Greene, R.S.B., Scott, K.M. \& McQueen, K.G., 2007. Recognition and characterisation of the aeolian component in soils in the Girilambone Region, north western New South Wales, Australia. Catena 69, 122 133.

Tolksdorf, J.F. \& Kaiser, K., 2012. Holocene aeolian dynamics in the European sand-belt as indicated by geochronological data. Boreas 41, 408-421. 
Vandenberghe, D.A.G., Derese, C., Kasse, C. \& van den Haute, P., 2013. Late Weichselian (fluvio-)aeolian sediments and Holocene drift-sands of the classic type locality in Twente (E Netherlands): a high-resolution dating study using optically stimulated luminescence. Quaternary Science Reviews 68, 96-113.

Velichko, A.A. \& Timirieva, S.N., 1995. Morphoscopy and morphometry of quartz grains from loess and buried soil layers. GeoJournal 36, 143-149.

Veski, S., Seppä, H., \& Ojala, A.E.K., 2004. Cold event at 8200 yr B.P. recorded in annually laminated lake sediments in eastern Europe. Geology 32, 681-684.

Veski, S., Seppä, H., Stančikaitė, M., Zernitskaya, V., Reitalu, T., Gryguc, G., Heinsalu, A., Stivrins, N., Amon, L., Vassiljev, J. \& Heiri, O., 2015. Quantitative summer and winter temperature reconstructions from pollen and chironomid data between 15 and $8 \mathrm{ka} \mathrm{BP}$ in the Baltic and Belarus area. Quaternary International 388, 4-11.

Visher, G.S., 1969. Grain size distribution and depositional processes. Journal of Sedimentary Research 39, 1074-1106.

Vos, K., Vandenberghe, N. \& Elsen, J., 2014. Surface textural analysis of quartz grains by scanning electron microscopy (SEM): From sample preparation to environmental interpretation. Earth-Science Reviews 128, 93-104.

Woronko, B., Zieliński, P. \& Sokołowski, R.J., 2015. Climate evolution during the Pleniglacial and Late Glacial as recorded in quartz grain morphoscopy of fluvial to aeolian successions of the European Sand Belt. Geologos 21, 89-103.

Young, N.E., Briner, J.P., Rood, D.H., Finkel, R.C., Corbett, L.B. \& Bierman, P.R., 2013. Age of the Fjord Stade moraines in the Disko Bugt region, western Greenland, and the 9.3 and 8.2 ka cooling events. Quaternary Science Reviews 60, 76-90.

Yu, S.-Y., Colman, S.M., Lowell, T.V., Milne, G.A., Fisher, T.G., Breckenridge, A., Boyd, M. \& Teller, J.T., 2010. Freshwater outburst from Lake Superior as a trigger for the cold event 9300 years ago. Science 328 (5983), 1262-1266.
Zeeberg, J., 1998. The European sand belt in eastern Europe - and comparison of Late Glacial dune orientation with GCM simulation results. Boreas 27, 127-139.

Zelčs, V. \& Markots, A., 2004. Deglaciation history of Latvia. [In:] J. Ehlers \& P.L. Gibbard (Eds), Quaternary Glaciations Extent and Chronology Part I: Europe, Developments in Quaternary Science. Elsevier, Amsterdam, 225-243.

Zelčs, V., Markots, A., Nartišs, M. \& Saks, T., 2011. Pleistocene Glaciations in Latvia. [In:] J. Ehlers, P.L. Gibbard \& P.D. Hughes (Eds.): Quaternary Glaciations - Extent and Chronology, Developments in Quaternary Science. Elsevier, Amsterdam, 221-229.

Zhang, P., Song, C., Yang, Y., Gao, H., Zhang, H., Liu, W.M., Pan, M.H., Liu, P., Hu, S.H. \& Xia, W.M., 2008. The significance and establishment of discriminant function with grain size of stable lacustrine sediment and eolian loess. Acta Sedimentologica Sinica 26, 501507.

Zhang, X., Li, Z., Li, P., Cheng, S., Zhang, Y., Tang, S. \& Wang, T., 2015. A model to study the grain size components of the sediment deposited in aeolian - fluvial interplay erosion watershed. Sedimentary Geology 330, 132-140.

Zhang, Z. \& Dong, Z., 2015. Grain size characteristics in the Hexi Corridor Desert. Aeolian Research 18, 55-67.

Zieliński, P., Sokołowski, R.J., Woronko, B., Fedorowicz, S., Jankowski, M. \& Standzikowski, K., 2016. Sandy deposition in a small dry valley in the periglacial zone of the Last Glacial Maxiumum: A case study from the Józefów site, SE Poland. Quaternary International 399, 58-71.

Zieliński, P., Sokołowski, R.J., Woronko, B., Jankowski, M., Fedorowicz, S., Zaleski, I., Molodkov, A. \& Weckwerth, P., 2015. The depositional conditions of the fluvio-aeolian succession during the last climate minimum based on the examples from Poland and NW Ukraine. Quaternary International 386, 30-41.

Manuscript received: 25 October 2016 Revision accepted: 20 December 2016 